\title{
Influence of mother nutrition during pregnancy and/or lactation on offspring food preference in experimental models
}

\author{
L. S. Santos ${ }^{a, b *}$, G. S. Cordeiro ${ }^{a, b}$, G. S. Perez ${ }^{a, b}$, D. A. E. Santo ${ }^{a, b}$, A. P. A. Macêdo ${ }^{a}$, \\ M. S. Lima ${ }^{a}$, I. B. C. Carneiro ${ }^{a, b}$, M. E. P. C. Machado ${ }^{a, b}$, T. C.B. J. Deiró ${ }^{a, b}$ and \\ J. M. Barreto-Medeiros ${ }^{a, b}$ \\ aEscola de Nutrição, Departamento de Ciências da Nutrição, Universidade Federal da Bahia, \\ Av. Araújo Pinho, 32, Canela, CEP 40110-150, Salvador, BA, Brasil \\ 'Programa de Pós-graduação em Alimentos, Nutrição e Saúde, Escola de Nutrição, Universidade Federal da Bahia, \\ Av. Araújo Pinho, 32, Canela, CEP 40110-150, Salvador, BA, Brasil \\ *e-mail: meirenut.ssa@gmail.com
}

Received: April 27, 2017 - Accepted: November 30, 2017 - Distributed: May 31, 2019

(With 1 figure)

\begin{abstract}
Introduction: Understanding associations between food preferences and maternal nutrition during pregnancy and lactation could inform efforts to understanding the obesity mechanisms and provide insight to prevent it. Objective: To identify studies that investigated the effects of nutritional interventions during the pregnancy and lactation on the food preferences of offspring. Method: The review was conducted with search for articles in the databases: Scopus, Pubmed, Medline, LILACS, Scielo and Science Direct. Exclusion criteria were used: reviews, human studies, studies with drugs or other substances not related to food. Results: At the end of the search in the databases, 176 references were found. After use the exclusion criteria, reading the titles, abstracts and full articles, were selected 11 articles to compose the review. Conclusion: The selected studies suggested that unbalanced nutrition in early life alters the food preference and neural components related to the consumption of fatty and sugary foods in offspring rodents.
\end{abstract}

Keywords: pregnancy, lactation, rats, diet, food preference.

\section{Influência da nutrição materna durante a gestação e/ou lactação na preferência alimentar da prole em modelos experimentais}

\begin{abstract}
Resumo
Introdução: O entendimento das associações entre as preferências alimentares e nutrição materna durante a gravidez e lactação poderia colaborar para a compreensão dos mecanismos da obesidade e fornecer informações para prevenir essa infermidade. Objetivo: Identificar estudos que investigaram os efeitos das intervenções nutricionais durante a gravidez e lactação em preferências alimentares dos descendentes. Método: A revisão foi conduzida com busca de artigos nas bases de dados: Scopus, Pubmed, Medline, Lilacs, Scielo e Science Direct. Os critérios de exclusão utilizados: revisões, estudos em humanos, estudos com drogas ou outras substâncias não-alimentares. Resultados: No final da pesquisa nas bases de dados, 176 referências foram encontradas. Depois de usar os critérios de exclusão, lendo os títulos, resumos e artigos completos, 11 artigos foram selecionados para compor a revisão. Conclusão: Os estudos selecionados sugeriram que a nutrição desequilibrada no início da vida altera a preferência alimentar e componentes neurais relacionadas com o consumo de alimentos gordurosos e açucarados em prole de roedores.
\end{abstract}

Palavras-chave: gravidez, lactação, ratos, dieta, preferência alimentar.

\section{Introduction}

The intrauterine life and early postnatal periods are considered critical moments of development due to the rapid growth and maturation of cells, organs and physiological systems. In these periods, the organism is susceptible to environmental changes, and the nutrient shortage or excess can be a capable factor of generating adaptations and promote health effects throughout individuals life
(Langley-Evans, 2006; Bayol et al., 2007; Oliveira et al., 2011). This event is related to phenotypic plasticity and can generate several effects, such as greater adiposity (Perez et al., 2015) and a higher intake of fatty and sugary foods (Gugusheff et al., 2013).

Experimental studies have found an association early exposure to nutritionally unbalanced diets and the preference 
for highly palatable foods (Gugusheff et al., 2013; Ong and Muhlhausler, 2011). In addition to this association, evidence suggests that exposure alters neural circuits, specifically components of the mesolimbic dopaminergic system, which acts as one of the central mechanisms in the choice of tasty food (Ong and Muhlhausler, 2011; Volkow et al., 2011; Ribeiro and Santos, 2013).

The dopamine system is a neural pathway, located in the cerebral cortex, where components work together to provide the release of dopamine in the nucleus accumbens (NAc), which act as a promoter of motivation for obtaining the reward (Volkow et al., 2011). Food with high density, high fat and sugar are considered rewards and their consumption is an important contributor to the development of chronic non-communicable such as obesity, that still keeps as an important public health problem. A survey conducted by the World Health Organization revealed an increasing prevalence of overweight and obesity in the world. According to this, in 2014, about $39 \%$ of the adult population was overweight, especially the countries in the Americas, including Brazil (World Health Organization, 2014).

However, despite the existing evidence about the influence of phenotypic plasticity in preference for fatty and sugary foods, until this moment, no review was conducted with the purpose of analyzing studies with various dietary interventions and the influence on food choice. In order to understand this issue, the aim of this review was to identify studies that investigated the effects of nutritional interventions during pregnancy and lactation on food preference in rats or mices.

\section{Methods}

The articles quest was held at the period from July to September 2015, in electronic databases Scopus, Pubmed, Medline, LILACS, Scielo and ScienceDirect. The search for articles was performed by two reviewers who recruited articles published in the year 2000 to September 2015, using combinations of the following key words in English and Portuguese:

Food preference; Diet; Phenotypic plasticity; Programming; Gestation; Lactation; Rats.

Exclusion criteria: reviews, human studies, studies with drugs or other substances not related to food.

The identified studies were evaluated according to the criteria of inclusion: studies with rats or mices which were exposed to some kind of diet during the intrauterine period of life and / or lactation.

The articles were pre-selected by reading the titles and later, by reading the summaries. After this stage, the articles resulting from the shortlist were read in full, and those who do not fit the established criteria were excluded from the review. For analysis of the studies, the informations about each one were summarized in a table.

\section{Results}

176 scientific articles were selected in the 6 surveyed databases. Of these, have been excluded: $33.52 \%$ presenting titles repeated, $57.38 \%$ after reading the abstracts and $2.84 \%$ after reading in full. In this way, $6.25 \%$ of all articles was included in the review, which corresponded to 11 works (Figure 1).

The main information and results presented by articles selected and included in this review were tabulated in Table 1.

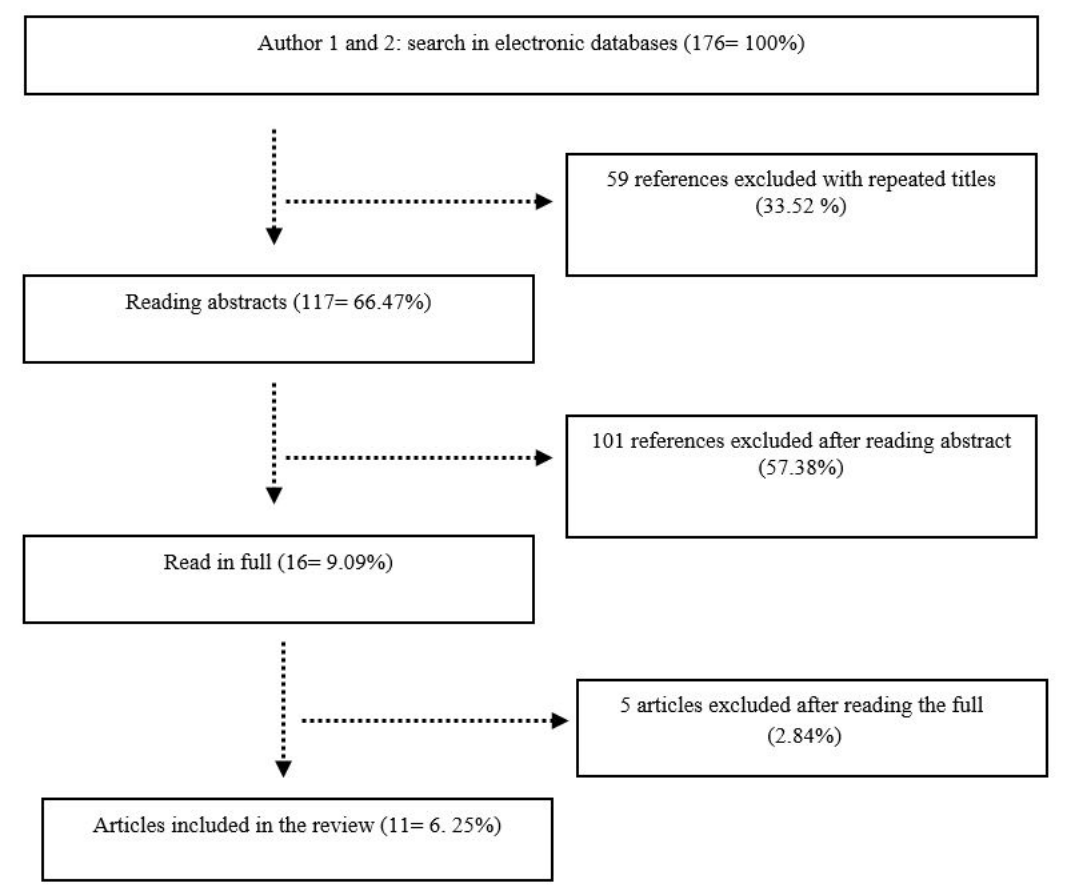

Figure 1. Flow of information obtained in different phases of review, adapted from Moher et al. (2009). 


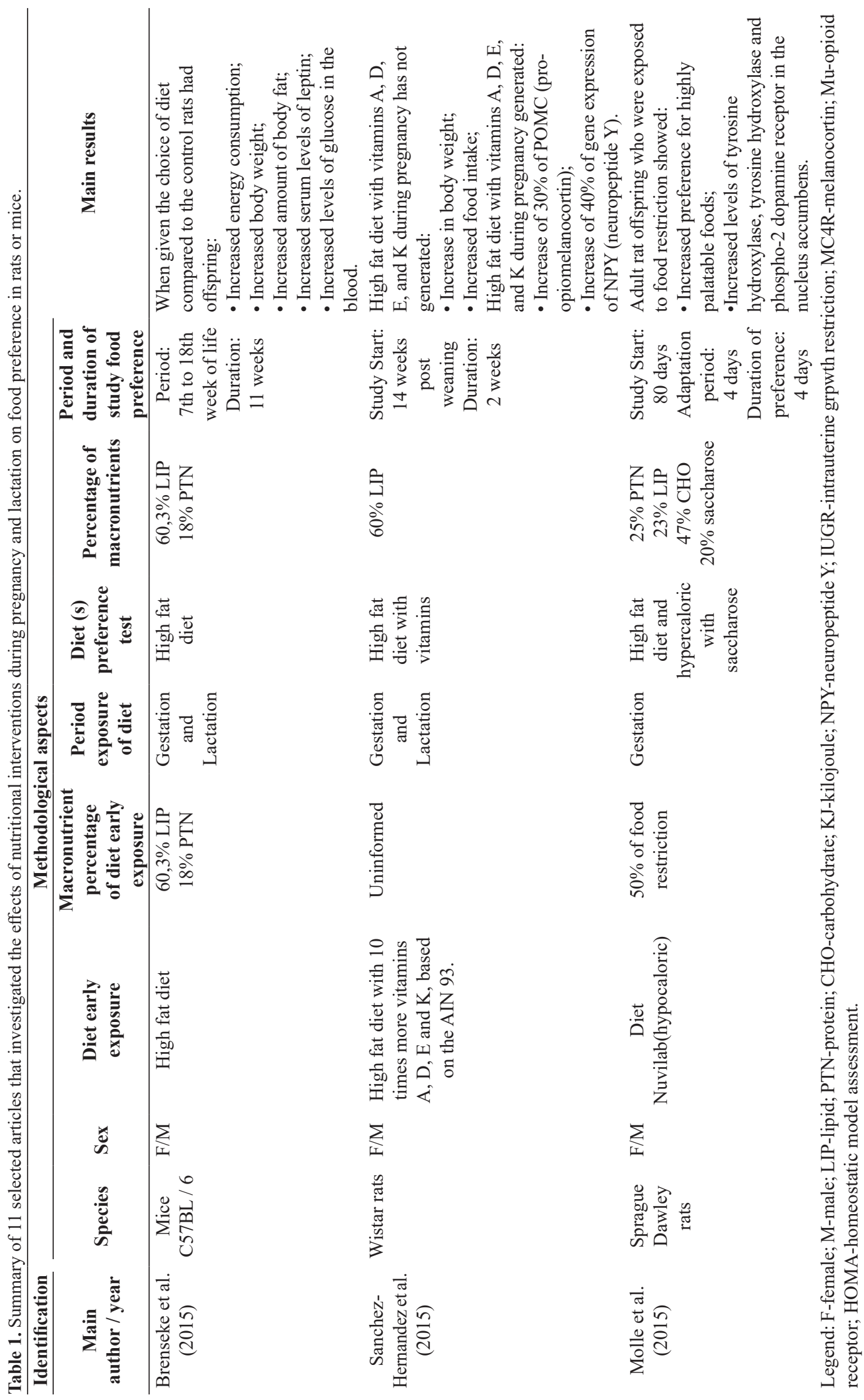




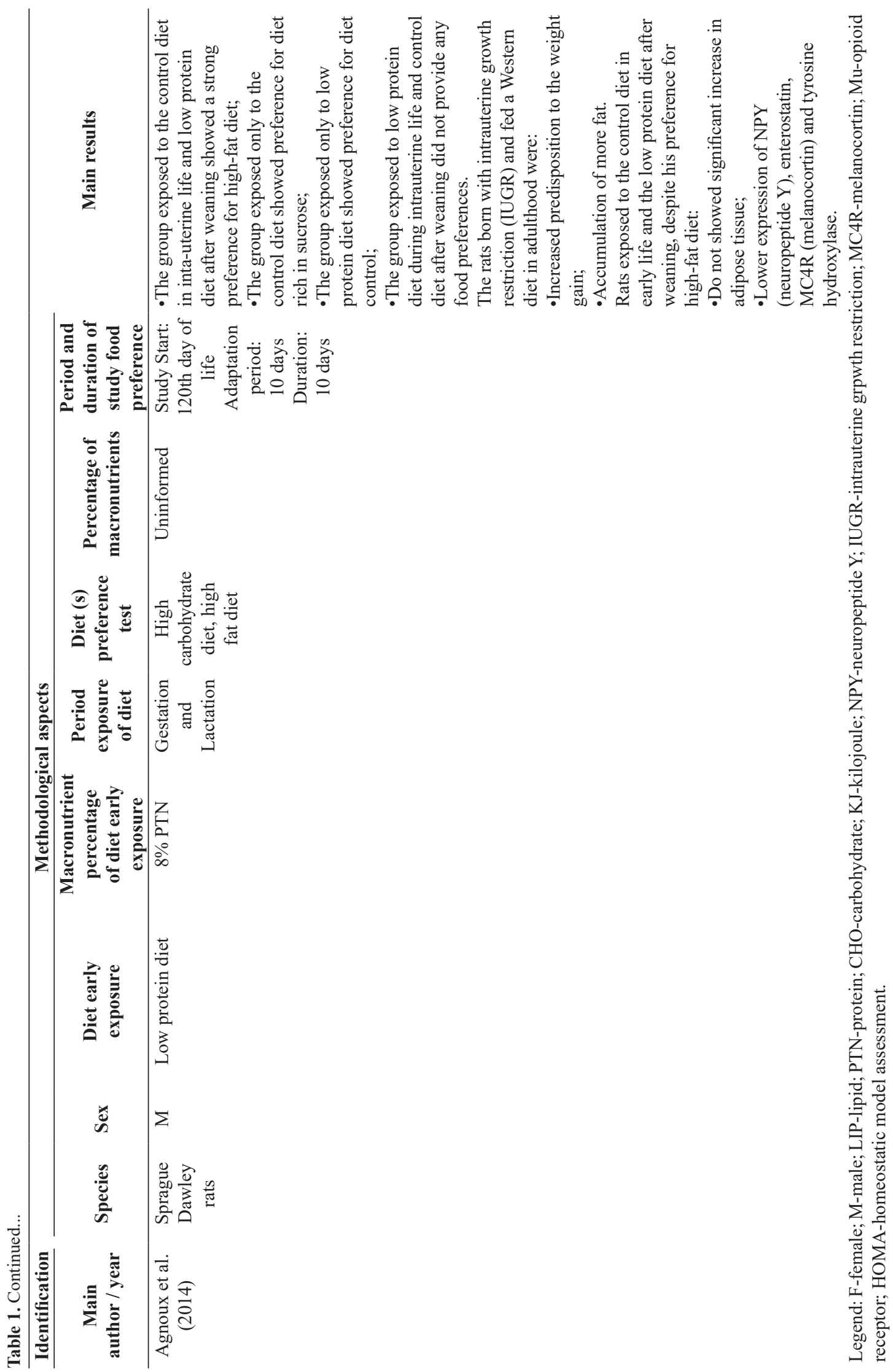




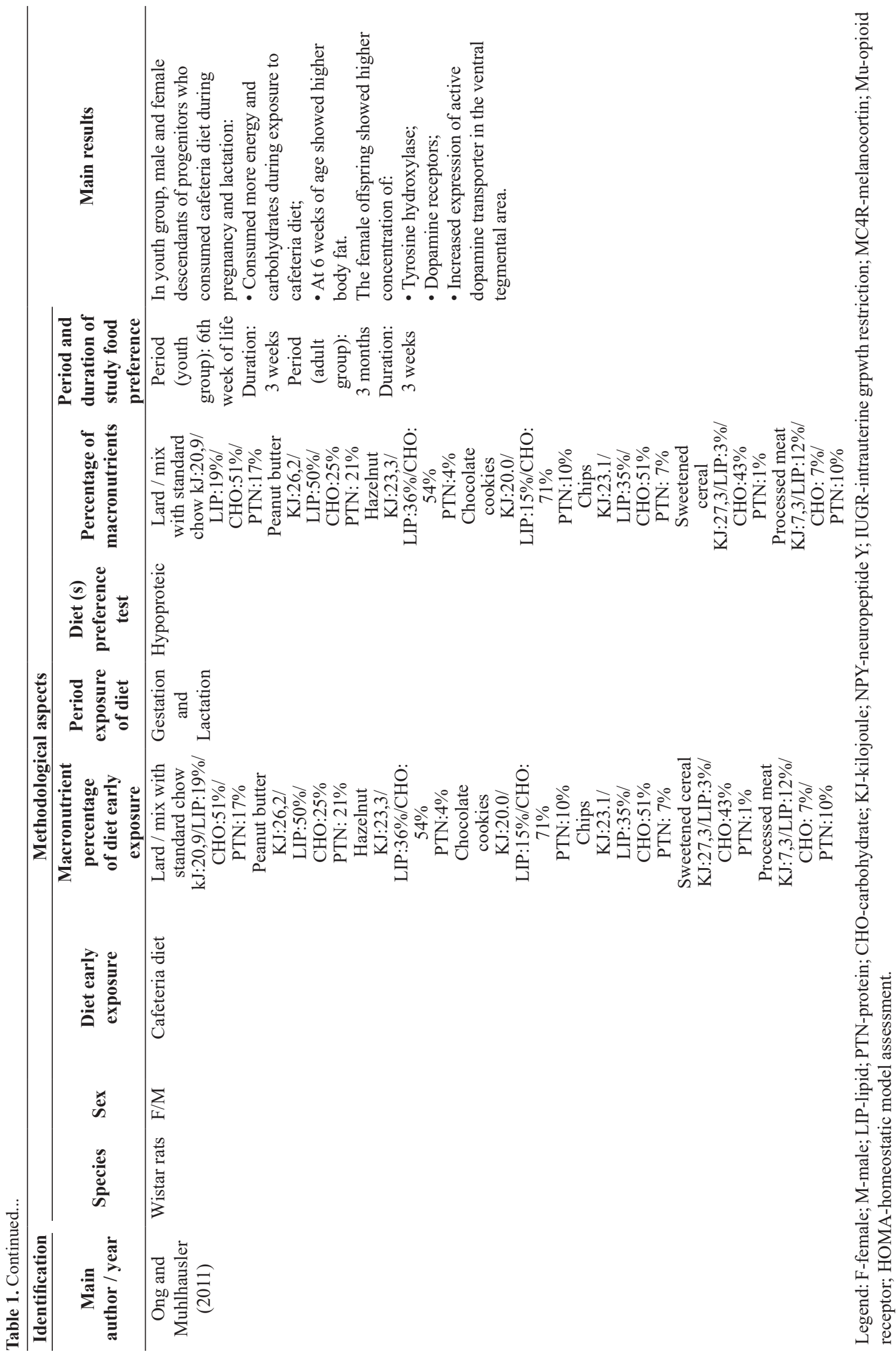




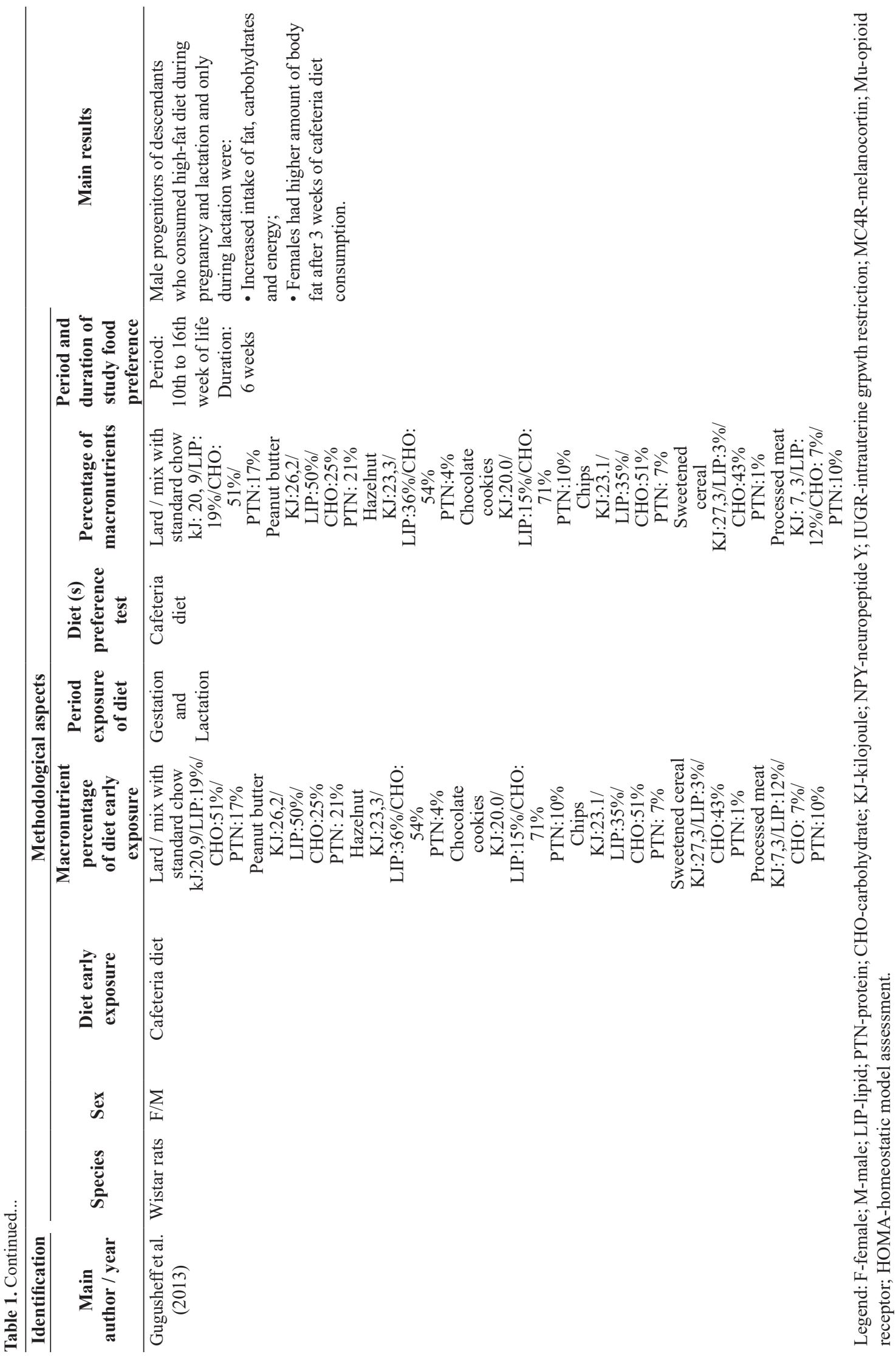




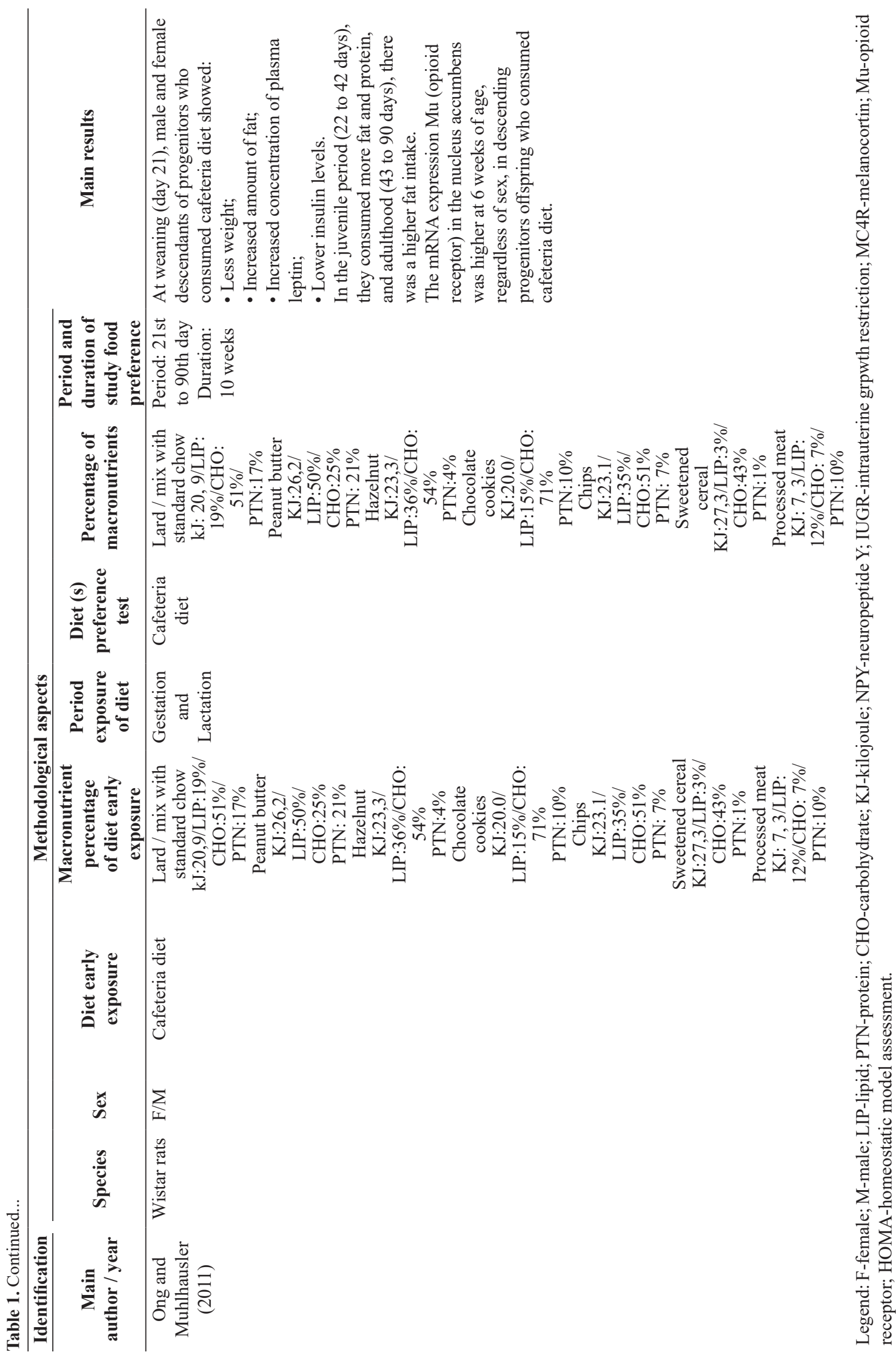




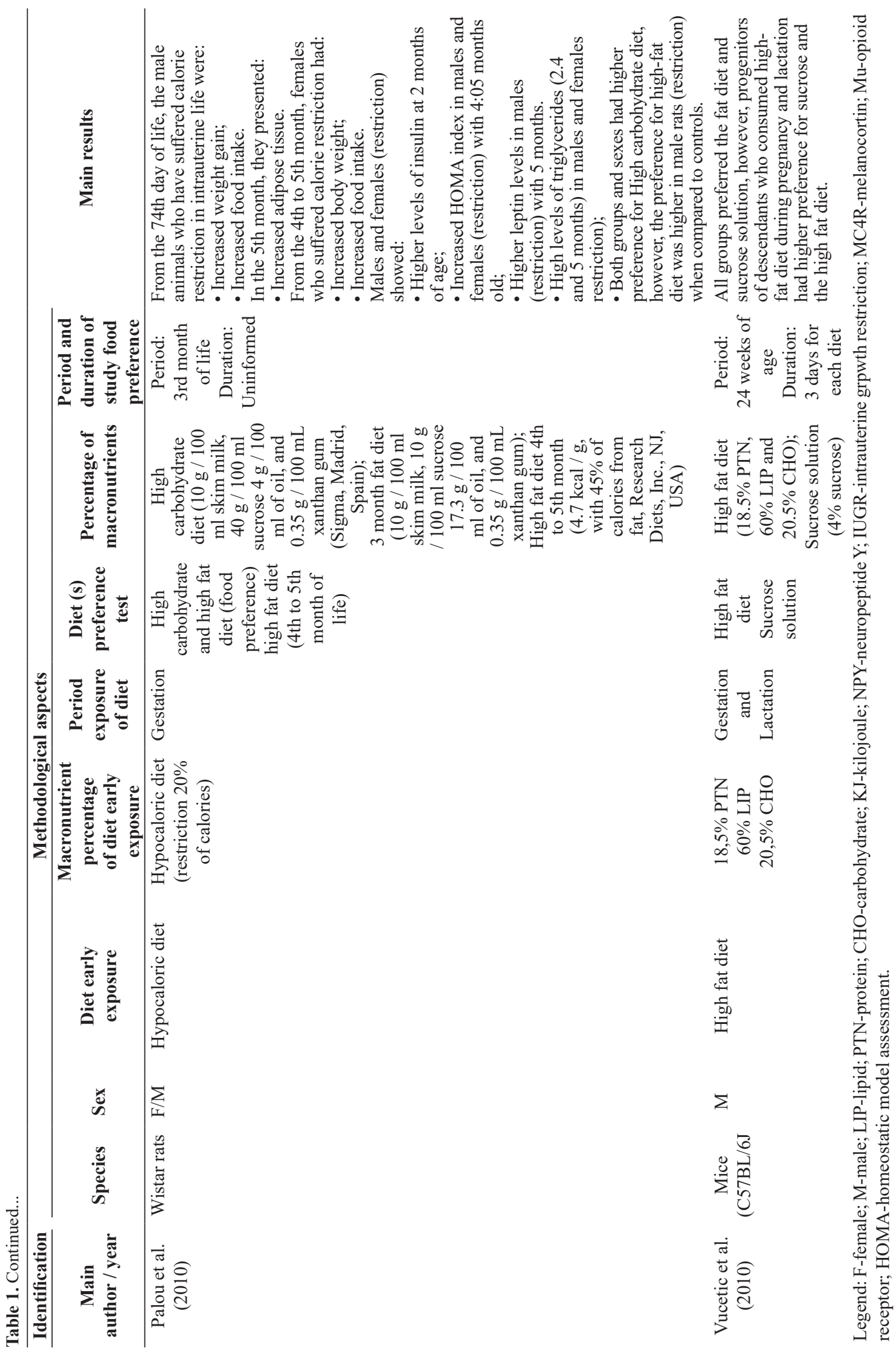




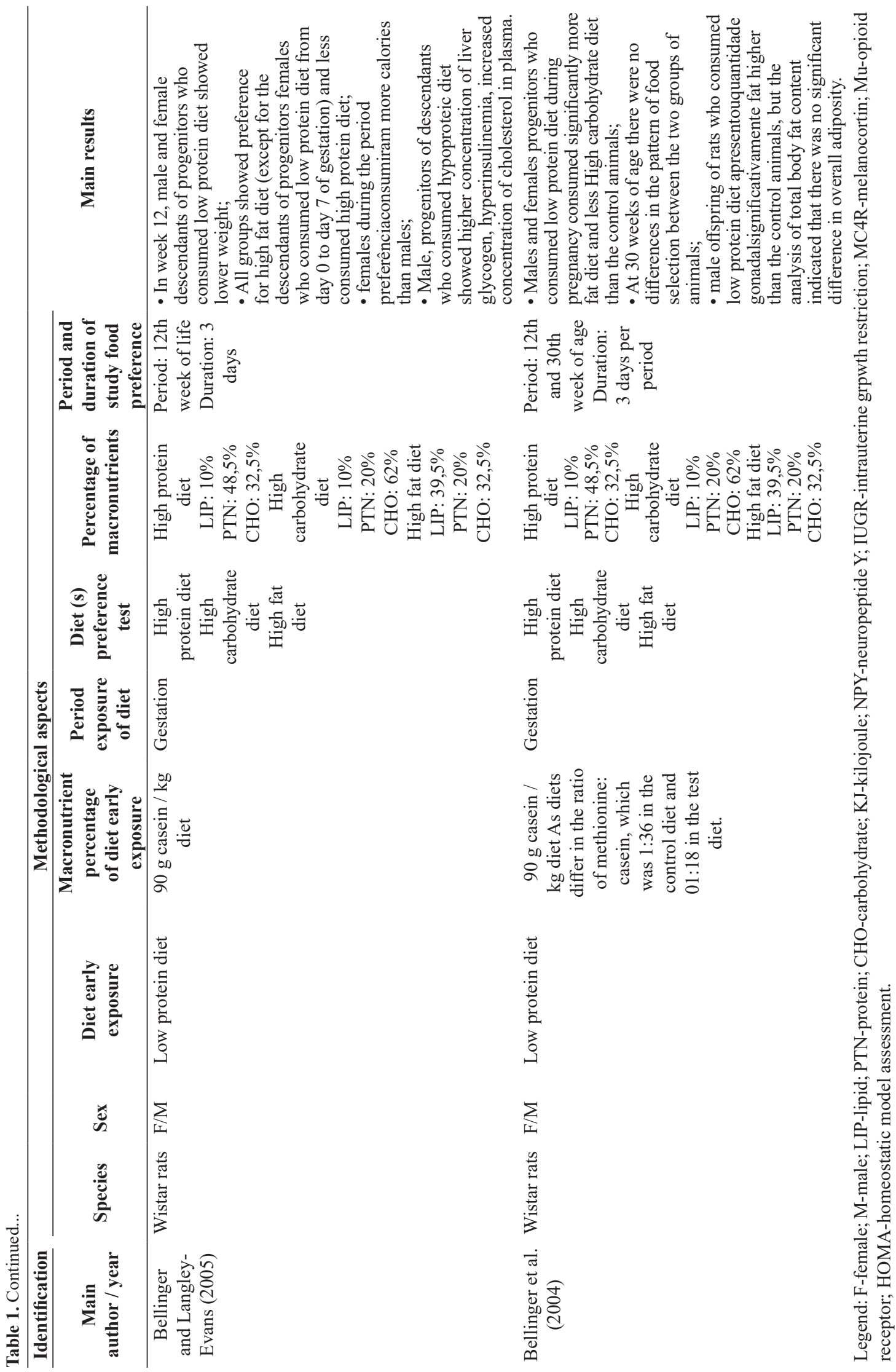




\section{Discussion}

The increased consumption of palatable food, rich in fats and sugars, are increasingly being associated with the emergence of chronic diseases, arousing, the scientific interest in the investigation of their effects at different stages of life.

The preference for these foods can lead to nutritional imbalance, and may be persistent, and contribute to the development of obesity and other chronic diseases in adulthood (Portella and Silveira, 2014).

\subsection{Species of animals}

There is a wide variety of rodent models used as test subjects. Among them are the species Zucker (Oana et al., 2005), Sprague Dawley (Molle et al., 2015), Long Evans (Ignar et al., 2011) and Wistar (Perez et al., 2015). The selected papers used the animal models with mice species C57BL / 6J (Vucetic et al., 2010; Brenseke et al., 2015), Wistar rats (Gugusheff et al., 2013; Ong and Muhlhausler, 2011; Bellinger, et al., 2004; Bellinger and Langley-Evans, 2005; Palou et al., 2010; Ong and Muhlhausler, 2014; SanchezHernandez et al., 2015) and Sprague Dawley (Molle et al., 2015; Agnoux et al., 2014).

The rodents are the species of animals most frequently used as guinea pigs in research, generally is selected according to the purpose of each study. This selection aims to facilitate the understanding about the results obtained in the research as well as considers the cost / benefit techniques to be used and physiological characteristics of animals, such as metabolism. The mice of the C57BL / 6J species are genetically modified animals and used in research to study diseases that affect humans, such as diabetes (Surwit et al., 1991). The Sprague Dawley model rats can be line prone to obesity or obesity resistant, and are mainly used in studies that seek to elucidate issues related to genetic predisposition (Shin et al., 2011). Rodents Wistar lineage do not have genetic mutations. They are frequently used frequently in research with the model of diet obesity induction, as in surveys conducted by Ong and Muhlhausler (2011) and Gugusheff et al. (2013). In both studies the authors used the cafeteria diet as a model of induction of obesity in Wistar rats during pregnancy and / or lactation and analyzed the effect of this induction in weight gain, food intake and metabolic parameters in offspring.

\subsection{Nutritional manipulation: types of diets}

The articles selected for this review used different types of diets in order to carry out the nutritional manipulation in early stages of development (pregnancy and / or lactation). From the selected papers, the most used diet were the high fat or cafeteria (Gugusheff et al., 2013; Ong and Muhlhausler, 2011; Vucetic et al., 2010; Brenseke et al., 2015; Ong and Muhlhausler, 2014). These diet are characterized by high content of fat and sugar in its composition, and when exposed to excess in the critical period of development (beginning of life), can influence an increasing preference for palatable food, predisposing to obesity and other chronic diseases in the animals (Bayol et al., 2007; Ong and Muhlhausler,
2014). Sanchez Hernandez et al (Sanchez-Hernandez et al., 2015) studied the repercussion of high fat diet intake in mice, besides having high fat content, were added vitamins (A, D, E and K). By exposing the animals to nutritional manipulation during the gestation period, the researchers showed that the rich high fat diet in vitamins did not change the weight and food intake. However, it was able to influence the hedonic development of pathways associated with the feeding preference. Despite results showed the negative effects of early life consumption of high fat diet, there is already evidence in literature that the effects of this kind of diet can potentially be overcome, or minimized, by exposure to a nutritionally balanced diet in adulthood (Ong and Muhlhausler, 2014).

Other types of diets used in nutritional manipulation studies are hypoproteic (Bellinger et al., 2004; Bellinger and Langley-Evans, 2005; Agnoux, et al., 2014) and hypocaloric (Molle et al., 2015; Palou et al., 2010). The hypoproteic diets are characterized by low protein content and the hypocaloric diets by calorie restriction that varies between studies and may be mild or severe restriction, depending on the objective of each research. When these diets are offered in the prenatal period, for example, can produce an adaptive response to the fetus in development (Bellinger et al., 2004). However, long-term changes, generated by adaptive responses may affect the descendants as changes in hormonal responsiveness, organs structure or gene expression and may contribute to metabolic disorders in adulthood (Bellinger et al., 2004).

The evidences found in the articles included in this review demonstrate the interest of the authors in reproduce the dietary pattern of modern society, considering that most of the articles used high fat or cafeteria diets as dietary manipulation model. Corroborating this hypothesis, data from the Brazilian Institute of Geography and Statistics showed that the Brazilian population increased consumption of high fat foods, and higher density as sausages, breads, cookies and sodas, as well as decreased consumption of less caloric foods, sources fiber, vitamins and minerals such as fruits and vegetables (Instituto Brasileiro de Geografia e Estatística, 2010), increasing the interest of scientists to investigate the effects of consumption of these types of diets.

\subsection{Nutritional manipulation in critical periods of development}

More than half of the selected studies conducted the nutritional manipulation in both period, pregnancy and lactation (Molle et al., 2015; Vucetic et al., 2010; Brenseke et al., 2015; Ong and Muhlhausler, 2014; Sanchez-Hernandez et al., 2015; Agnoux et al., 2014). The critical periods of development, as are called the stages of pregnancy and lactation, have fundamental importance for the development of physiological systems. Environmental changes in these periods are related to disturbances in the short and long term metabolism (Oliveira et al., 2011; Barker et al., 1993; Barreto-Medeiros et al., 2002, 2004). This phenomenon is called metabolic programming and 
refers to the ability of organism adaptation to insults caused in early periods of life (Lucas, 1998). Over the years and with the evolution of research on this subject, other terminologies have emerged as phenotypic plasticity (Pigliucci, 2001), which retains the same meaning related to the adaptive response of the organism, but less deterministic than the word programming.

The modulation of phenotypic plasticity in the face of adversity of environment, such as changes in the supply of nutrients, happens in order to meet the demands of the individual and benefit the physiological systems. However, with the emergence of new environmental changes, it may enable the appearance of disorders such as weight gain (Srinivasan et al., 2006; Couvreur et al., 2011), hyperglycemia (Taylor et al., 2005), cardiovascular disorders (Poston, 2012), mood disorders (Peleg-Raibstein et al., 2012), increased body fat deposition (Perez et al., 2015; Benkalfat et al., 2011) hypercholesterolemia (Oliveira et al., 2011) and preference for palatable foods (rich in sugars and fats) (Gugusheff et al., 2013; Ong and Muhlhausler, 2011).

\subsection{Study of food preference}

The food choice is an important contributor to health, thus, factors that influence food preference and its impact need to be continuously studied. Human studies show that exposure to certain stimuli of taste in intrauterine life and lactation may alter food preferences in later periods. Food preferences tests on infants showed that early exposure to different flavors can lead to increased acceptance and preferences for these flavors later in life (Liem and Mennella, 2002; Mennella and Beauchamp, 2002).

Experimental studies have been highlight this thematic. Rodents have been used as a model for the analysis of multiple brain circuits, including the mesolimbic dopaminergic system, strongly related to food choices. In these animals, dopamine receptors can be detected in the mesolimbic system at the beginning of embryonic life, being vulnerable to environmental stresses, as the nutrition, in this period (Gugusheff et al., 2015).

The study of food preference in most selected papers in this review was performed only in adulthood (Gugusheff et al., 2013; Molle et al., 2015; Vucetic et al., 2010; Bellinger et al., 2004; Bellinger and Langley-Evans, 2005; Palou et al., 2010; Sanchez-Hernandez et al., 2015; Agnoux et al., 2014). The authors sought to understand the influence of nutritional manipulation during pregnancy and / or lactation on food choice of the animals in later life. Ong and Mühlhäusler (Ong and Muhlhausler, 2014), conducted the evaluation of the food preference of the animals in two specific moments, in the juvenile period (42 days) and adulthood (90 days), while Brenseke et al. (2015) and Ong and Muhlhausler (2011) have chosen study the preference for a longer period, including both the juvenile period and the adulthood. As well as the period chosen for study food preference, the duration of the study also differed among the articles of this review, ranging from 3 to 70 days.

\subsection{The main effects of the consumption of nutritionally unbalanced diets related to food preference}

Methodological differences of the selected articles were been observed from the animal species chosen as a model for research to the period duration of the study and the food preference. These differences make more difficult a precise analysis about the methodology of study. However, despite the methodological differences, the results of the work were similar. Approximately half of selected studies showed that nutritional manipulation in early periods of development increased the preference for high-fat diet and / or sugars (Molle et al., 2015; Vucetic et al., 2010; Bellinger et al., 2004; Bellinger and Langley-Evans, 2005; Palou et al., 2010). 30\% showed that the exposed animals exhibited greater intake of carbohydrate, lipid and / or energy for the study of food preference (Ong and Muhlhausler, 2011; Gugusheff et al., 2013; Brenseke et al., 2015; Ong and Muhlhausler, 2014), and two of the studies included in this review (20\%) showed no difference in preference between animals (Sanchez-Hernandez et al., 2015; Agnoux et al., 2014). However, in both studies there were changes of components related to food choice as the pro-opiomelanocortin and neuropeptide Y (Sanchez-Hernandez et al., 2015) and enterostatin, melanocortin and tyrosine hydroxylase (Agnoux et al., 2014), enzyme responsible for the synthesis of dopamine which presents higher expression when there is excessive intake palatable food (Huang et al., 2005; Vucetic et al., 2011), enabling greater activation in the dopamine signaling, associated with the largest consumption of tasty food (Ong and Muhlhausler, 2014).

Disturbances in leptin concentration were also presented as results in the papers included in this review (Ong and Muhlhausler, 2011; Brenseke et al., 2015; Palou et al., 2010). The leptin influences the development of neural circuitry that regulates food intake. Leptin receptors located in the dopaminergic neurons act in inhibiting the activity of dopamine, which can be triggered by exposure to palatable foods (Ong and Muhlhausler, 2011). Thus, increased serum concentrations of leptin can promote changes in the dopaminergic system and consequently in food intake (Ong and Muhlhausler, 2011; Hommel et al., 2006).

In this way the exposure to a nutritionally unbalanced diet in critical periods of development can lead to increased consumption of highly palatable foods (high in fats and sugars) and changes in neural components involved in pathways related to food preference. Even the animals exposed to low-calorie and hypoproteic diets during intrauterine and postnatal life, showed higher intake of fat and / or carbohydrate in adulthood, suggesting that regardless of inadequacy, unbalanced nutrition influences on food consumption in later periods.

\section{References}

AGNOUX, A.M., ANTIGNAC, J.P., SIMARD, G., POUPEAU, G., DARMAUN, D., PARNET, P. and ALEXANDRE-GOUABAU, M.C., 2014. Time window-dependent effect of perinatal maternal 
protein restriction on insulin sensitivity and energy substrate oxidation in adult male offspring. American Journal of Physiology. Regulatory, Integrative and Comparative Physiology, vol. 307, no. 2, pp. R184-R197. http://dx.doi.org/10.1152/ajpregu.00015.2014. PMid:24808498.

BARKER, D.J., GLUCKMAN, P.D., GODFREY, K.M., HARDING, J.E., OWENS, J.A. and ROBINSON, J.S., 1993. Fetal nutrition and cardiovascular disease in adult life. Lancet (London, England), vol. 341, no. 8850, pp. 938-941. PMid:8096277.

BARRETO-MEDEIROS, J.M., CABRAL-FILHO, J.E., SOUZA, S.L., SILVA, S.R.F., SILVA, C.M., DEIRÓ, T.C., MONTEIRO, J.M., GUEDES, R.C., MANHAES-DE-CASTRO, C. and MANHAES-DE-CASTRO, R., 2002. Early malnourished rats are not affected by anorexia induced by a selective serotonin reuptake inhibitor in adult life. Nutritional Neuroscience, vol. 5, no. 3, pp. 211-214. http://dx.doi.org/10.1080/10284150290029197. PMid:12041877.

BARRETO-MEDEIROS, J.M., FEITOZA, E.G., MAGALHAES, K., CABRAL-FILHO, J.E., MANHAES-DE-CASTRO, F.M., DE-CASTRO, C.M. and MANHAES-DE-CASTRO, R., 2004. Malnutrition during brain growth spurt alters the effect of fluoxetine on aggressive behavior in adult rats. Nutritional Neuroscience, vol. 7, no. 1, pp. 49-52. http://dx.doi.org/10.1080/10284150420 00194595. PMid:15085558.

BAYOL, S.A., FARRINGTON, S.J. and STICKLAND, N.C., 2007. A maternal 'junk food' diet in pregnancy and lactation promotes an exacerbated taste for 'junk food' and a greater propensity for obesity in rat offspring. British Journal of Nutrition, vol. 98, no. 4, pp. 843-851. http://dx.doi.org/10.1017/S0007114507812037. PMid:17697422.

BELLINGER, L. and LANGLEY-EVANS, S.C., 2005. Fetal programming of appetite by exposure to a maternal low-protein diet in the rat. Clinical Science, vol. 109, no. 4, pp. 413-420. http:// dx.doi.org/10.1042/CS20050127. PMid:15992360.

BELLINGER, L., LILLEY, C. and LANGLEY-EVANS, S.C., 2004. Prenatal exposure to a maternal low-protein diet programmes a preference for high-fat foods in the young adult rat. The British Journal of Nutrition, vol. 92, no. 3, pp. 513-520. http://dx.doi. org/10.1079/BJN20041224. PMid:15469656.

BENKALFAT, N.B., MERZOUK, H., BOUANANE, S., MERZOUK, S.A., BELLENGER, J., GRESTI, J., TESSIER, C. and NARCE, M., 2011. Altered adipose tissue metabolism in offspring of dietary obese rat dams. Clinical Science, vol. 121, no. 1, pp. 19-28. http://dx.doi.org/10.1042/CS20100534. PMid:21288203.

BRENSEKE, B., BAHAMONDE, J., TALANIAN, M., KORNFEIND, E., DALY, J., COBB, G., ZHANG, J., PRATER, M.R., DAVIS, G.C. and GOOD, D.J., 2015. Mitigating or exacerbating effects of maternal-fetal programming of female mice through the food choice environment. Endocrinology, vol. 156, no. 1, pp. 182-192. http://dx.doi.org/10.1210/en.2014-1523. PMid:25386832.

COUVREUR, O., FEREZOU, J., GRIPOIS, D., SEROUGNE, C., CRÉPIN, D., AUBOURG, A., GERTLER, A., VACHER, C.M. and TAOUIS, M., 2011. Unexpected long-term protection of adult offspring born to high-fat fed dams against obesity induced by a sucrose-rich diet. PLoS One, vol. 6, no. 3, pp. e18043. http:// dx.doi.org/10.1371/journal.pone.0018043. PMid:21464991.

GUGUSHEFF, J.R., ONG, Z.Y. and MUHLHAUSLER, B.S., 2015. The early origins of food preferences: targeting the critical windows of development. The FASEB Journal, vol. 29, no. 2, pp. 365-373. http://dx.doi.org/10.1096/fj.14-255976. PMid:25466884.

GUGUSHEFF, J.R., VITHAYATHIL, M., ONG, Z.Y. and MUHLHAUSLER, B.S., 2013. The effects of prenatal exposure to a 'junk food' diet on offspring food preferences and fat deposition can be mitigated by improved nutrition during lactation. Journal of Developmental Origins of Health and Disease, vol. 4, no. 5, pp. 348-357. http://dx.doi.org/10.1017/S2040174413000330. PMid:24970728.

HOMMEL, J.D., TRINKO, R., SEARS, R.M., GEORGESCU, D., LIU, Z.W., GAO, X.B., THURMON, J.J., MARINELLI, M. and DILEONE, R.J., 2006. Leptin receptor signaling in midbrain dopamine neurons regulates feeding. Neuron, vol. 51, no. 6, pp. 801-810. http://dx.doi.org/10.1016/j.neuron.2006.08.023. PMid:16982424.

HUANG, X.F., YU, Y., ZAVITSANOU, K., HAN, M. and STORLIEN, L., 2005. Differential expression of dopamine D2 and D4 receptor and tyrosine hydroxylase mRNA in mice prone, or resistant, to chronic high-fat diet-induced obesity. Brain Research. Molecular Brain Research, vol. 135, no. 1-2, pp. 150-161. http:// dx.doi.org/10.1016/j.molbrainres.2004.12.013. PMid:15857678.

IGNAR, D.M., GOETZ, A.S., NOBLE, K.N., CARBALLO, L.H., STROUP, A.E., FISHER, J.C., BOUCHERON, J.A., BRAINARD, T.A., LARKIN, A.L., EPPERLY, A.H., SHEARER, T.W., SORENSEN, S.D., SPEAKE, J.D. and HOMMEL, J.D., 2011. Regulation of ingestive behaviors in the rat by GSK1521498, a novel micro-opioid receptor-selective inverse agonist. The Journal of Pharmacology and Experimental Therapeutics, vol. 339, no. 1, pp. 24-34. http://dx.doi.org/10.1124/jpet.111.180943. PMid:21712426.

INSTITUTO BRASILEIRO DE GEOGRAFIA E ESTATÍSTICA - IBGE. Pesquisa de orçamentos familiares, 2008-2009: aquisição alimentar domiciliar per capita, Brasil e grandes regiões. Rio de Janeiro: IBGE, 2010.

LANGLEY-EVANS, S.C., 2006. Developmental programming of health and disease. The Proceedings of the Nutrition Society, vol. 65, no. 1, pp. 97-105. http://dx.doi.org/10.1079/PNS2005478. PMid:16441949.

LIEM, D.G. and MENNELLA, J.A., 2002. Sweet and sour preferences during childhood: role of early experiences. Developmental Psychobiology, vol. 41, no. 4, pp. 388-395. http:// dx.doi.org/10.1002/dev.10067. PMid:12430162.

LUCAS, A., 1998. Programming by early nutrition: an experimental approach. The Journal of Nutrition, vol. 128, no. 2, (suppl.), pp. 401S-406S. http://dx.doi.org/10.1093/jn/128.2.401S. PMid:9478036.

MENNELLA, J.A. and BEAUCHAMP, G.K., 2002. Flavor experiences during formula feeding are related to preferences during childhood. Early Human Development, vol. 68, no. 2, pp. 71-82. http://dx.doi.org/10.1016/S0378-3782(02)00008-7. PMid:12113993.

MOHER, D., LIBERATI, A., TETZLAFF, J. and ALTMAN, D.G., 2009. Preferred reporting items for systematic reviews and meta-analyses: the PRISMA statement. PLoS Medicine, vol. 6, no. 7, pp. e1000097. http://dx.doi.org/10.1371/journal. pmed.1000097. PMid:19621072.

MOLLE, R.D., LAUREANO, D.P., ALVES, M.B., REIS, T.M., DESAI, M., ROSS, M.G. and SILVEIRA, P.P., 2015. Intrauterine growth restriction increases the preference for palatable foods and affects sensitivity to food rewards in male and female adult rats. 
Brain Research, vol. 1618, pp. 41-49. http://dx.doi.org/10.1016/j. brainres.2015.05.019. PMid:26006109.

OANA, F., TAKEDA, H., HAYAKAWA, K., MATSUZAWA, A., AKAHANE, S., ISAJI, M. and AKAHANE, M., 2005. Physiological difference between obese (fa/fa) Zucker rats and lean Zucker rats concerning adiponectin. Metabolism: Clinical and Experimental, vol. 54, no. 8, pp. 995-1001. http://dx.doi. org/10.1016/j.metabol.2005.02.016. PMid:16092047.

OLIVEIRA, T.W., LEANDRO, C.G., DEIRÓ, T.C.J., PEREZ, G.S., SILVA, D.F., DRUZIAN, J.I., COUTO, R.D. and BARRETO-MEDEIROS, J.M., 2011. A perinatal palatable highfat diet increases food intake and promotes hypercholesterolemia in adult rats. Lipids, vol. 46, no. 11, pp. 1071-1074. http://dx.doi. org/10.1007/s11745-011-3604-7. PMid:21847693.

ONG, Z.Y. and MUHLHAUSLER, B.S., 2011. Maternal "junkfood" feeding of rat dams alters food choices and development of the mesolimbic reward pathway in the offspring. The FASEB Journal, vol. 25, no. 7, pp. 2167-2179. http://dx.doi.org/10.1096/ fj.10-178392. PMid:21427213.

ONG, Z.Y. and MUHLHAUSLER, B.S., 2014. Consuming a low-fat diet from weaning to adulthood reverses the programming of food preferences in male, but not in female, offspring of " junk food'-fed rat dams. Acta Physiologica (Oxford, England), vol. 210, no. 1, pp. 127-141. http://dx.doi.org/10.1111/apha.12132. PMid:23746329.

PALOU, M., PRIEGO, T., SÁNCHEZ, J., TORRENS, J.M., PALOU, A. and PICÓ, C., 2010. Moderate caloric restriction in lactating rats protects offspring against obesity and insulin resistance in later life. Endocrinology, vol. 151, no. 3, pp. 10301041. http://dx.doi.org/10.1210/en.2009-0934. PMid:20068006.

PELEG-RAIBSTEIN, D., LUCA, E. and WOLFRUM, C., 2012. Maternal high-fat diet in mice programs emotional behavior in adulthood. Behavioural Brain Research, vol. 233, no. 2, pp. 398404. http://dx.doi.org/10.1016/j.bbr.2012.05.027. PMid:22633920.

PEREZ, G.S., SANTOS, L.S., CORDEIRO, G.S., PARAGUASSÚ, G.M., ATHANAZIO, D.A., COUTO, R.D., DEIRÓ, T.C.B.J., MANHAES-DE-CASTRO, R. and BARRETO-MEDEIROS, J.M., 2015. Maternal and post-weaning exposure to a high fat diet promotes visceral obesity and hepatic steatosis in adult rats. Nutrición Hospitalaria, vol. 32, no. 4, pp. 1653-1658. PMid:26545531.

PIGLIUCCI, M. Phenotypic plasticity: beyond nature and nurture. Baltimore: Johns Hopkins University Press, 2001.

PORTELLA, A.K. and SILVEIRA, P.P., 2014. Neurobehavioral determinants of nutritional security in fetal growth-restricted individuals. Annals of the New York Academy of Sciences, vol. 1331, no. 1, pp. 15-33. http://dx.doi.org/10.1111/nyas. 12390. PMid:24650246.

POSTON, L., 2012. Maternal obesity, gestational weight gain and diet as determinants of offspring long term health. Best Practice \& Research. Clinical Endocrinology \& Metabolism, vol. 26, no. 5, pp. 627-639. http://dx.doi.org/10.1016/j.beem.2012.03.010. PMid:22980045.

RIBEIRO, G. and SANTOS, O., 2013. Recompensa alimentar: mecanismos envolvidos e implicações para a obesidade. Revista
Portuguesa de Endocrinologia Diabetes Metabolism, vol. 8, no. 2, pp. 82-88. http://dx.doi.org/10.1016/j.rpedm.2013.09.001.

SANCHEZ-HERNANDEZ, D., POON, A.N., KUBANT, R., KIM, H., HUOT, P.S., CHO, C.E., PANNIA, E., PAUSOVA, Z. and ANDERSON, G.H., 2015. A gestational diet high in fatsoluble vitamins alters expression of genes in brain pathways and reduces sucrose preference, but not food intake, in Wistar male rat offspring. Applied Physiology, Nutrition, and Metabolism = Physiologie Appliquee, Nutrition et Metabolisme, vol. 40, no. 4, pp. 424-431. http://dx.doi.org/10.1139/apnm-2014-0480. PMid:25787712.

SHIN, A.C., TOWNSEND, R.L., PATTERSON, L.M. and BERTHOUD, H.R., 2011. "Liking" and "wanting" of sweet and oily food stimuli as affected by high-fat diet-induced obesity, weight loss, leptin, and genetic predisposition. American Journal of Physiology. Regulatory, Integrative and Comparative Physiology, vol. 301, no. 5, pp. R1267-R1280. http://dx.doi.org/10.1152/ ajpregu.00314.2011. PMid:21849633.

SRINIVASAN, M., KATEWA, S.D., PALANIYAPPAN, A., PANDYA, J.D. and PATEL, M.S., 2006. Maternal high-fat diet consumption results in fetal malprogramming predisposing to the onset of metabolic syndrome-like phenotype in adulthood. American Journal of Physiology. Endocrinology and Metabolism, vol. 291, no. 4, pp. E792-E799. http://dx.doi.org/10.1152/ ajpendo.00078.2006. PMid:16720630.

SURWIT, R.S., SELDIN, M.F., KUHN, C.M., COCHRANE, C. and FEINGLOS, M.N., 1991. Control of expression of insulin resistance and hyperglycemia by different genetic factors in diabetic C57BL/6J mice. Diabetes, vol. 40, no. 1, pp. 82-87. http://dx.doi. org/10.2337/diab.40.1.82. PMid:2015977.

TAYLOR, P.D., MCCONNELL, J., KHAN, I.Y., HOLEMANS, K., LAWRENCE, K.M., ASARE-ANANE, H., PERSAUD, S.J., JONES, P.M., PETRIE, L., HANSON, M.A. and POSTON, L., 2005. Impaired glucose homeostasis and mitochondrial abnormalities in offspring of rats fed a fat-rich diet in pregnancy. American Journal of Physiology. Regulatory, Integrative and Comparative Physiology, vol. 288, no. 1, pp. R134-R139. http:// dx.doi.org/10.1152/ajpregu.00355.2004. PMid:15388492.

VOLKOW, N.D., WANG, G.J. and BALER, R.D., 2011. Reward, dopamine and the control of food intake: implications for obesity. Trends in Cognitive Sciences, vol. 15, no. 1, pp. 37-46. http:// dx.doi.org/10.1016/j.tics.2010.11.001. PMid:21109477.

VUCETIC, Z., KIMMEL, J. and REYES, T.M., 2011. Chronic high fat diet drives postnatal epigenetic regulation of mu-opioid receptor in the brain. Neuropsychopharmacology, vol. 36, no. 6, pp. 1199-1206. http://dx.doi.org/10.1038/npp.2011.4. PMid:21326195.

VUCETIC, Z., KIMMEL, J., TOTOKI, K., HOLLENBECK, E. and REYES, T.M., 2010. Maternal high-fat diet alters methylation and gene expression of dopamine and opioid-related genes. Endocrinology, vol. 151, no. 10, pp. 4756-4764. http://dx.doi. org/10.1210/en.2010-0505. PMid:20685869.

WORLD HEALTH ORGANIZATION - WHO. Obesity and overweight [online] 2014 [viewed 20 December 2015]. Available from: http://www.who.int/mediacentre/factsheets/fs311/en/ 